GRASAS Y ACEITES 65 (2)

April-June 2014, e024

ISSN-L: 0017-3495

doi: http://dx.doi.org/10.3989/gya.122413

\title{
Fast screening of turkish olive oil by NMR spectroscopy for geographical determination and discrimination purposes
}

\author{
S. $\mathrm{Ok}^{\mathrm{a}, \mathrm{b}, \mathbb{}}$ \\ ${ }^{a}$ School of Earth Sciences, The Ohio State University, 125 South Oval Mall, 43210, Columbus, OH, USA \\ Institut für Chemie, Universität Osnabrück, 49069, Osnabrück, Germany \\ Correspondence: ok.12@osu.edu
}

Submitted: 11 December 2013; Accepted: 23 December 2013

SUMMARY: The main goal of this study is to rapidly screen olive oil contents by acquiring one dimensional (1D) ${ }^{1} \mathrm{H}$ NMR spectra of 38 samples from Turkey, The Middle East, and Libya. The quantitative analysis of the ${ }^{1} \mathrm{H}$ NMR helped in distinguishing the geographical origin of the olive oil samples. The intensity of ${ }^{1} \mathrm{H}$ NMR variables was submitted to the statistical method, analysis of variance (ANOVA). As a result of combining the NMR data and ANOVA, olive oils were discriminated based on regional origin rather than province. This less time consuming discriminative screening by ${ }^{1} \mathrm{H}$ NMR does not require any further analysis of the olive oil, including oxidative stability measurements or gas chromatography. The possibility of determining authenticity, even in an olive growing area of a small village was also shown. The two-dimensional (2D) non-invasive ${ }^{1} \mathrm{H}$ DOSY NMR experiment, known as "NMR chromatography", was used to determine the olive oil sub-fraction.

KEYWORDS: Geographical origin; ${ }^{1}$ H DOSY NMR,${ }^{1} H$ NMR quantitative analysis; Olive oil; Sub-fraction determination

RESUMEN: Detección rápida de aceites de oliva de Turquía mediante espectroscopía de RMN para la determinación y discriminación geográfica. El objetivo es conocer de manera rápida el contenido de aceite de oliva mediante la adquisición de espectros de ${ }^{1} \mathrm{H}$ RMN de una dimensión (1D). El estudio se ha realizado con 38 muestras procedentes de Turquía, Oriente Medio y Libia. El análisis cuantitativo de ${ }^{1} \mathrm{H}$ RMN ayudó a distinguir el origen geográfico de las muestras de aceites de oliva. La intensidad de las señales de ${ }^{1} \mathrm{H}$ RMN se sometió a estudio estadístico mediante análisis de varianza (ANOVA). Como resultado de la combinación de los datos de RMN y ANOVA, los aceites de oliva fueron discriminados por origen regional antes que por provincia. Esta técnica de discriminación rápida por ${ }^{1} \mathrm{H} \mathrm{RMN}$ no requiere ningún análisis adicional de los aceites de oliva mediante estudios de estabilidad a la oxidación o cromatografía de gases. También se demostró la posibilidad de determinar la autenticidad, incluso en el área de cultivo del olivo de una pequeña aldea. Los experimentos de RMN bi-dimensionales (2D) no invasiva ${ }^{1} \mathrm{H}$ DOSY, conocido como “cromatografía RMN", se utilizó en la determinación de subfracciones de aceites de oliva.

PALABRAS CLAVE: Aceite de oliva; Análisis cuantitativo; Determinación de subfracciones; ${ }^{1} \mathrm{H} R M N ;{ }^{1} H \mathrm{RMN}$ DOSY; Procedencia geográfica

Citation/Cómo citar este artículo: Ok S. 2014. Fast screening of turkish olive oil by NMR spectroscopy for geographical determination and discrimination purposes. Grasas Aceites 65 (2): e024. doi: http://dx.doi.org/10.3989/gya.122413.

Copyright: (C) 2014 CSIC. This is an open-access article distributed under the terms of the Creative Commons Attribution-Non Commercial (by-nc) Spain 3.0 Licence. 


\section{INTRODUCTION}

Olive oil, a "natural fruit juice", is extracted from the fruit of Olea europea L. by mechanical techniques or other physical procedures (Mannina and Sobolev, 2011; Sacchi et al.,1998; Alonso-Salces et al., 2010a) which do not alter the glyceric structure of the oil and preserve its properties (Alonso-Salces et al., 2010a). For food safety reasons, there are international regulations established to define the genuineness of olive oil (altering from seed oils) and to determine its quality grade (extra virgin, virgin, pomace, etc.) (Zeiner et al., 2005, and Zamora et al., 2001). In olive oil safety analysis, one of the major concerns is the geographical origin (Alonso-Salces et al., 2010a; Zeiner et al., 2005; Alonso-Salces et al., 2010b). Olive oil has two organic components: a major fraction of triglycerides with $>98 \%$, and different substitution patterns due to the length, degree and kind of unsaturation of the acyl groups, and unsaponifiable minor fraction with $<2 \%$ such as squalene, $\alpha$-tocopherol, phytosterols, phenolic compounds, carotenoids, etc. (Guillén and Ruiz, 2001; Alonso-Salces et al., 2010a; Sacchi et al., 1997; Alonso-Salces et al., 2010b). In order to determine a geographical origin, analyzing both the major and minor discriminative constituents of olive oils is essential.

Among the different leading countries in olive production, olive oils from Spain, Italy and Greece have been analyzed in detail (Sacchi et al., 1998; AlonsoSalces et al., 2010a; Alonso-Salces et al., 2010b; D'Imperio et al., 2007; Sacchi et al., 1996; Hatzakis et al., 2008). However, there are limited reports and insufficient data on the geographical discrimination of olive oils and olive processing from countries such as Jordan and Turkey (Andjelkovic et al., 2009; Degirmencioglu, 2011). In most studies on Turkish olive oil for instance, the main focus was the olive oil from North Aegean (Andjelkovic et al., 2009; Ilyasoglu et al., 2010), the western and south eastern regions of Turkey (Ocakoglu et al., 2009), despite the fact that there are five more distinct olive growing regions in Turkey: The Aegean region (western Turkey), the Marmara region (north-western Turkey), the Mediterranean region (southern Turkey), the Southeast Anatolian region, and the Black Sea region (northern Turkey), listed from the highest percentage production to the lowest one (Arslan and Schreiner, 2012). In contributing to the Turkish olive oil analysis, Andjelkovic et al. (2009) analyzed only ten commercial olive oils from North Aegean of Turkey by gas chromatography (GC) while Ilyasoglu et al. (2010) applied liquid chromatography-mass spectrometry (LC-MS) to analyzing only thirteen samples from the same region. In the present work, the number of samples is higher, and there are samples from three additional countries.
Nuclear magnetic resonance (NMR) spectroscopy, employed in olive oil analysis (Zamora et al., 2001; Sacchi et al., 1997; D'Imperio et al., 2007; Sacchi et al., 1996; Guillén and Ruiz, 2001), has advantages of higher sensitivity, intrinsic linearity, higher precision, and shorter experimental time (Sacchi et al., 1996). Among other techniques used for analyzing olive oil, the addition of iodine to react quantitatively with the double bonds of linoleic or linolenic acids is time consuming, and rapid screening by NMR may be of interest to the industry (Guillén et al., 2001). There is also a possibility of applying recent advanced NMR experiments such as diffusion ordered spectroscopy (DOSY) to oils (Socha et al., 2010).

The aim of this work is to contribute to the geographical origin determination and discrimination of olive oils from the non-European side of the Mediterranean region by combining NMR and statistical methodology ANOVA. For this purpose, single pulse $500-\mathrm{MHz}{ }^{1} \mathrm{H}$ NMR spectra of 38 olive oil samples from five well-defined distinct regions of Turkey, in addition to analyzing olive oils from Jordan, Palestine and Libya were recorded. Quantitative data of selected resonances was evaluated with the Analysis of Variance (ANOVA) method. ${ }^{1} \mathrm{H}$ DOSY NMR was also applied for determining sub-fractions such as sterols in olive oil samples instead of chromatography. The determination of minor components is made in order to figure out some trends related to the geographical origin of the olive oils and to compare the discriminative ability of the current data to similar works on subfraction determination of olive oils from several countries (AlonsoSalces et al., 2010b).

\section{MATERIALS AND METHODS}

\subsection{Chemicals}

Deuterated chloroform $\left(\mathrm{CHCl}_{3}\right.$-d), $99.8 \%$ atom $\%$ D stabilized with $0.5 \% \mathrm{wt}$ silver foil, were purchased from Aldrich.

\subsection{Olive Oils}

All olives were harvested by hand during the period from November 2010 to January 2011 and processed via mechanical techniques without any chemical treatment to olive oil by local producers. The olive oils were "virgin" oils since they were not refined or further processed upon production. Olive oils were obtained from several cities in Turkey, Jordan, Palestine and Libya. The olive oils were kept at $18{ }^{\circ} \mathrm{C}$ in a dark room where air conditioning worked continuously. Thus, prior to and during 
analysis, all the samples were protected from light. The NMR experiments were conducted as soon as the olive oils were received.

\subsection{NMR Spectroscopy}

Olive oils $(150 \mu \mathrm{L})$ were placed in $5 \mathrm{~mm}$ NMR tubes, dissolved in chloroform-d $(0.6 \mathrm{~mL})$, the NMR tubes were sealed. ${ }^{1} \mathrm{H}$ NMR data were acquired on a JEOL $500 \mathrm{MHz}$ Lambda instrument with a multi-nuclei $5 \mathrm{~mm}$ solution probe $(50 \mathrm{TH} 5 / \mathrm{FG} 2)$. The ${ }^{1} \mathrm{H}$ NMR spectra were acquired with a recycle delay time of $10 \mathrm{~s}$, and with 16 repetitions. The proton spectra were internally referenced to the signal of the solvent at $7.25 \mathrm{ppm}$. The chosen delay time was sufficient, $5^{*} \mathrm{~T}_{1}$, to enable quantitative analysis (Segre and Mannina, 1997; Alonso-Salces et al., 2010a). ${ }^{1}$ H DOSY NMR data were acquired on a Bruker 400WB Plus spectrometer operating at a Larmor frequency of $400.1 \mathrm{MHz}$ for ${ }^{1} \mathrm{H}$ equipped with a $5 \mathrm{~mm}$ BBO probe including a $\mathrm{z}$-axis gradient coil with a maximum strength of $50 \mathrm{G} \cdot \mathrm{cm}^{-1}$. ${ }^{1} \mathrm{H}$ DOSY NMR experiments were performed in 16 steps using the standard Bruker ledbpgp2s pulse program with stimulated echo and longitudinal eddy delay with bipolar gradients and two spoil gradients. The recycle delay was $10 \mathrm{~s}$, while gradient recovery delays were $80 \mathrm{~ms}$, and diffusion times were $100 \mathrm{~ms}$. The individual rows of the $2 \mathrm{D}$ diffusion databases were phased and baseline corrected.

\subsection{Data Analysis}

The quantitative analysis of the region between $0 \mathrm{ppm}$ and $4 \mathrm{ppm}$ in ${ }^{1} \mathrm{H}$ NMR spectra of the olive oil samples is made with reference to the literature (Sacchi et al., 1997; Sacchi et al., 1996). The resonances at $0.98 \mathrm{ppm}(\mathrm{E}), 0.88 \mathrm{ppm}(\mathrm{F}), 2.01$ ppm (C), and 2.77 (A) arise from the following functional groups having a different number of protons, respectively:- $\boldsymbol{C H}_{3}$ (terminal group) ((Ln (18:3)); (3H), $-\boldsymbol{C H}_{3}$ (terminal group) ((L (18:2)) $(3 \mathrm{H})+(\mathrm{O}(18: 1))(3 \mathrm{H})+$ saturated fatty acyl $(\mathrm{S})(3 \mathrm{H})$; 9H), $-\boldsymbol{C H}_{2}-\mathrm{CH}=\mathrm{CH}$ (allylic group) $((\mathrm{L}(18: 2))(4 \mathrm{H})$ $+(\operatorname{Ln}(18: 3))(4 \mathrm{H})+(\mathrm{O}(18: 1))(4 \mathrm{H}) ; 12 \mathrm{H}), \mathrm{CH}=\mathrm{CH}-$ $\mathrm{CH}_{2}-\mathrm{CH}=\mathrm{CH}$ (diallylic group) $((\mathrm{L}(18: 2))(2 \mathrm{H})+(\mathrm{Ln}$ $(18: 3))(4 \mathrm{H}) ; 6 \mathrm{H})$. The- $\mathrm{CH}_{3}(\mathrm{E})$ chemical shift of $\mathrm{Ln}$ (18:3) is $\sim 0.10 \mathrm{ppm}$ de-shielded with respect to the analogous terminal groups of the other major fatty acyls. This is attributed to the de-shielding of $-\mathrm{CH}_{3}$ (E) by the nearby double bond electrons. The same de-shielding effect also explains the $\sim 0.76 \mathrm{ppm}$ difference between the signals of allylic $(\mathrm{C})$ and diallylic (A)- $\mathrm{CH}_{2}$ groups (Alonso-Salces et al., 2010a; Alonso-Salces et al., 2010b; Sacchi et al., 1996). The assignments of the ${ }^{1} \mathrm{H}$ NMR signals of the triglycerides are already well known (Segre and Mannina,
1997; Sacchi et al., 1996; Guillén and Ruiz, 2001). The integral value of each signal is proportional to the number of nuclei contributing to that signal. Taking the multiplicity of proton atoms per functional group into account, the relative content of each group is directly derived. The integral of the lowest intensity peak arising from the terminal- $\mathrm{CH}_{3}$ of $(\operatorname{Ln}(18: 3))(E)$ is taken as 1 . The integrals of the remaining peaks are determined with respect to the integral value of $\mathrm{E}$. The integral values of the peaks (E, A, C, F) are compared to the number of corresponding protons.

$$
\begin{gathered}
\mathrm{CH}_{3}(\mathrm{Ln})=\mathrm{E} \\
\mathrm{CH}(\mathrm{Ln})=\mathrm{E} / 3(\text { eq. } 1)
\end{gathered}
$$

The content of $\operatorname{Ln}(18: 3)$ is determined by dividing the integral value of $E$ at $0.98 \mathrm{ppm}$ with 3 due to the three hydrogen of the terminal group of $\mathrm{Ln}$ (18:3).

$$
\begin{gathered}
\mathrm{CH}_{2}(\mathrm{~L})+2 * \mathrm{CH}_{2}(\mathrm{Ln})=\mathrm{A} \\
2 * \mathrm{CH}(\mathrm{L})+4 * \mathrm{CH}(\mathrm{Ln})=\mathrm{A} \\
\mathrm{CH}(\mathrm{L})=[\mathrm{A}-4 * \mathrm{CH}(\mathrm{Ln})] / 2(e q .2)
\end{gathered}
$$

Then taking the multiplicity of the diallylic protons into account, the integral value of $\mathrm{A}$ at $2.77 \mathrm{ppm}$ yields the content of $\mathrm{L}$ (18:2).

$$
\begin{gathered}
2 * \mathrm{CH}_{2}(\mathrm{~L})+2 * \mathrm{CH}_{2}(\mathrm{Ln})+2 * \mathrm{CH}_{2}(\mathrm{O})=\mathrm{C} \\
4 * \mathrm{CH}(\mathrm{L})+4 * \mathrm{CH}(\mathrm{Ln})+4 * \mathrm{CH}(\mathrm{O})=\mathrm{C} \\
\mathrm{CH}(\mathrm{O})=[\mathrm{C}-4 * \mathrm{CH}(\mathrm{L})-4 * \mathrm{CH}(\mathrm{Ln})] / 4(\text { eq. 3) }
\end{gathered}
$$

The relative amount of $\mathrm{O}(18: 1)$ is calculated referring to the allylic protons, so the integral value of $\mathrm{C}$ at $2.01 \mathrm{ppm}$.

$$
\begin{gathered}
\mathrm{CH}_{3}(\mathrm{~L})+\mathrm{CH}_{3}(\mathrm{O})+\mathrm{CH}_{3}(\mathrm{~S})=\mathrm{F} \\
3 * \mathrm{CH}(\mathrm{L})+3 * \mathrm{CH}(\mathrm{O})+3 * \mathrm{CH}(\mathrm{S})=\mathrm{F} \\
\mathrm{CH}(\mathrm{S})=[\mathrm{F}-3 * \mathrm{CH}(\mathrm{L})-3 * \mathrm{CH}(\mathrm{O})] / 3(e q .4)
\end{gathered}
$$

Similarly, the content of $\mathrm{S}$ is measured from the integral value of $\mathrm{F}$ arising from the terminal $\mathrm{CH}_{3}$ protons of free acids at $0.88 \mathrm{ppm}$. Each fatty acyl value obtained from the equations is summed, followed by dividing the value of each fatty acyl with the sum and multiplying the result by 100 . The integration of each peak in the ${ }^{1} \mathrm{H}$ NMR spectra is repeated 6 times using the iNMR software to get average and standard deviations (see Table 1 showing the geographical origins of olive oil samples, and the relative contents of each fatty acyl in olive oil samples). 
TABLE 1. Percentage fraction of Ln (18:3), Ln (18:2), O (18:1), and S in olive oils from different regions, towns and villages of Turkey.

MR: The Marmara Region (northwestern Turkey), AR: The Aegean Region (western Turkey), MeR: The Mediterranean Region (southern Turkey), SeR: The Southeastern Region, BSR: Black Sea Region (northern Turkey). The clustering of the ANOVA analysis based on the origin of a city. For ANOVA Harmonic Mean Sample Size $=6.000$ was used and subset for alpha=.05

\begin{tabular}{|c|c|c|c|c|c|c|c|c|c|}
\hline \multirow[b]{2}{*}{ Region (S\#) } & \multirow[b]{2}{*}{ City } & \multirow[b]{2}{*}{ Town } & \multirow[b]{2}{*}{ Village } & \multicolumn{4}{|c|}{ Fraction of fatty acyl components in olive oils ( $\%$ ) } & \multirow{2}{*}{\multicolumn{2}{|c|}{$\begin{array}{c}\begin{array}{c}\text { L (18:2) acyl } \\
\text { ANOVA results } \\
\text { using Tukey's test }\end{array} \\
\text { Sig. }\end{array}$}} \\
\hline & & & & Ln & $\mathbf{L}$ & $\mathbf{O}$ & $\mathbf{S}$ & & \\
\hline MR (1) & Balıkesir & Ayvalık & - & $1.3 \pm 0.1$ & $9.0 \pm 0.2$ & $70.3 \pm 1.1$ & $19.5 \pm 1.1$ & 8.95 & 0.2 \\
\hline MR (2) & Balıkesir & Ayvalık & Mutlu & $1.4 \pm 0.1$ & $7.4 \pm 0.7$ & $71.3 \pm 1.3$ & $19.8 \pm 1.2$ & 7.4 & 0.2 \\
\hline MR (3) & Balıkesir & Gömeç (1) & - & $1.3 \pm 0.1$ & $8.9 \pm 0.2$ & $71.4 \pm 1.3$ & $18.5 \pm 1.3$ & 8.87 & 0.2 \\
\hline MR (4) & Balıkesir & Gömeç (2) & - & $1.7 \pm 0.1$ & $8.4 \pm 0.2$ & $69.7 \pm 0.1$ & $20.4 \pm 0.1$ & 8.38 & 0.2 \\
\hline MR (5) & Balıkesir & Gönen & - & $1.6 \pm 0.1$ & $6.4 \pm 0.2$ & $72.3 \pm 0.6$ & $19.8 \pm 0.6$ & 6.25 & 0.1 \\
\hline MR (6) & Bursa & Gemlik & - & $2.1 \pm 0.1$ & $8.9 \pm 0.1$ & $70.1 \pm 0.8$ & $18.9 \pm 0.8$ & 8.9 & 0.2 \\
\hline $\operatorname{MR}(7)$ & Çanakkale & Eceabat & B.anafartalar & $1.7 \pm 0.1$ & $10.8 \pm 0.5$ & $67.5 \pm 0.7$ & $20.1 \pm 1.1$ & 10.77 & 1.0 \\
\hline MR (8) & Yalova & Armutlu & - & $1.9 \pm 0.1$ & $9.4 \pm 0.3$ & $69.8 \pm 0.4$ & $18.9 \pm 0.5$ & 9.38 & 0.4 \\
\hline MR (9) & Yalova & Altınova & - & $1.3 \pm 0.1$ & $7.3 \pm 0.4$ & $72.4 \pm 0.9$ & $19.0 \pm 0.9$ & 7.33 & 0.1 \\
\hline MR (10) & Yalova & Altınova & - & $1.4 \pm 0.1$ & $6.8 \pm 0.1$ & $70.4 \pm 1.2$ & $21.4 \pm 1.1$ & 6.82 & 0.2 \\
\hline MR (11) & Yalova & Altınova & - & $1.4 \pm 0.1$ & $7.4 \pm 0.2$ & $71.0 \pm 0.7$ & $20.3 \pm 0.7$ & 7.37 & 0.1 \\
\hline AR (12) & Aydin & Çine & Akcaova & $2.0 \pm 0.1$ & $7.7 \pm 0.2$ & $68.5 \pm 0.7$ & $21.9 \pm 0.6$ & 7.65 & 1.0 \\
\hline AR (13) & İzmir & Bağyurdu & - & $1.7 \pm 0.1$ & $5.9 \pm 0.2$ & $75.2 \pm 0.6$ & $17.2 \pm 0.6$ & 6.07 & 0.1 \\
\hline AR (14) & İzmir & Bağyurdu & Erbiller & $1.8 \pm 0.1$ & $6.0 \pm 0.4$ & $74.0 \pm 1.2$ & $18.1 \pm 1.1$ & 5.87 & 0.1 \\
\hline AR (15) & İzmir & Bayındır & - & $1.4 \pm 0.1$ & $3.4 \pm 0.2$ & $79.4 \pm 0.4$ & $15.7 \pm 0.5$ & 3.42 & 1.0 \\
\hline AR (16) & İzmir & Kemalpaşa & - & $1.5 \pm 0.1$ & $6.5 \pm 0.2$ & $72.8 \pm 0.8$ & $19.3 \pm 0.7$ & 6.47 & 0.1 \\
\hline AR (17) & İzmir & Kemalpaşa & Ulucak & $1.3 \pm 0.1$ & $10.9 \pm 0.1$ & $70.9 \pm 1.1$ & $17.0 \pm 1.1$ & 10.87 & 1.0 \\
\hline AR (18) & İzmir & Torbalı (1) & - & $1.7 \pm 0.1$ & $7.4 \pm 0.2$ & $72.5 \pm 0.8$ & $18.5 \pm 1.0$ & 7.38 & 0.2 \\
\hline AR (19) & İzmir & Torbalı (2) & - & $1.5 \pm 0.1$ & $5.6 \pm 0.3$ & $72.6 \pm 0.9$ & $20.3 \pm 1.0$ & 5.62 & 0.1 \\
\hline AR (20) & Manisa & Kırkağaç & - & $1.5 \pm 0.1$ & $6.7 \pm 0.3$ & $72.6 \pm 0.6$ & $19.1 \pm 0.8$ & 6.02 & 0.1 \\
\hline AR (21) & Manisa & Soma & - & $1.6 \pm 0.1$ & $6.0 \pm 0.2$ & $72.7 \pm 0.8$ & $19.7 \pm 1.0$ & 6.72 & 0.1 \\
\hline MeR (22) & Antalya & Alanya & Çamlıca & $1.9 \pm 0.1$ & $14.2 \pm 0.5$ & $64.1 \pm 1.1$ & $19.9 \pm 1.0$ & 14.22 & 1.0 \\
\hline MeR (23) & Hatay & Altınözü & - & $1.6 \pm 0.1$ & $9.1 \pm 0.2$ & $67.7 \pm 0.3$ & $21.6 \pm 0.3$ & 8.95 & 0.4 \\
\hline MeR (24) & Hatay & Samandağ 1 & - & $3.0 \pm 0.1$ & $31.9 \pm 0.6$ & $38.6 \pm 0.6$ & $26.5 \pm 0.6$ & 31.87 & 1.0 \\
\hline SeR (25) & Gaziantep & - & - & $1.8 \pm 0.1$ & $8.4 \pm 0.4$ & $69.0 \pm 0.4$ & $20.9 \pm 0.2$ & 8.38 & 0.2 \\
\hline SeR (26) & Gaziantep & Nizip & - & $1.6 \pm 0.1$ & $3.4 \pm 0.3$ & $74.6 \pm 0.6$ & $20.4 \pm 0.8$ & 3.43 & 1.0 \\
\hline BSR (27) & Artvin & Yusufeli & - & $1.5 \pm 0.1$ & $9.7 \pm 0.2$ & $74.7 \pm 0.3$ & $14.2 \pm 0.3$ & 9.72 & 0.1 \\
\hline
\end{tabular}

\subsection{Statistical Analysis}

${ }^{1}$ HNMR data were analyzed by analysis of variance (ANOVA) using Tukey's test at a p level $<0.05(5 \%$ significance level) with SPSS software. The $\mathrm{p}$ level $<0.05$ (5\% significance level) was the treatment as a borderline acceptable error level. The ANOVA analysis was performed on the percentage fraction of the fatty acyl contents, Linolenoyl (Ln, 18:3), Linoleoyl (L, 18:2), Oleoyl (O, 18:1), and Saturated (S) fatty acyls, obtained from the intensities of ${ }^{1} \mathrm{H}$ NMR resonances.

\section{RESULTS}

Figure 1 shows a typical ${ }^{1} \mathrm{H}$ NMR spectrum with the letter and number labels, while the peaks of major concerns are the ones labeled with both letter and number. There is no evidence of free fatty acids, which would appear in rancid oil. Major constituents of olive oil are esters of glycerol and fatty acids (Sacchi et al., 1997). Olive oil contains $70-80 \%$ oleoyl (monounsaturated fatty acyl) $(18: 1)$, a low level of polyunsaturated acids (linoleoyl fatty acyl (18:2) and less than 1\% linolenoyl fatty acyl (18:3)) and saturated fatty acyls (palmitic and stearic acyls) (Sacchi et al., 1997; Alonso-Salces et al., 2010a; Sacchi et al., 1996; Guillén and Ruiz, 2001). In the current report, the first interest is in fatty acyl content determination for geographical discrimination.

The advantage of ${ }^{1} \mathrm{H}$ NMR is that a different chemical environment of the hydrogen isotope is reflected in the NMR spectra with sharp signals. The distinct spectral lines are related to the chemical 


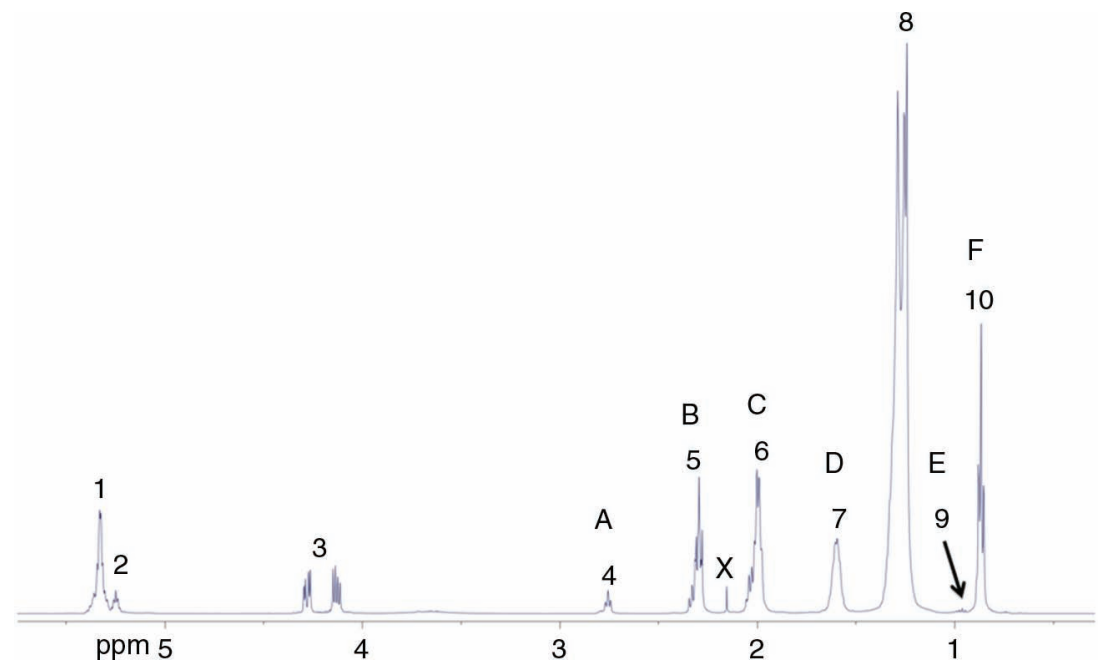

FIgURE 1. ${ }^{1} \mathrm{H}$ NMR spectrum of olive oil from Yalova/Armutlu. The peak labeled $\mathrm{x}$ is at $2.16 \mathrm{ppm}$, and attributed to the tocopherol fraction.

nature of the hydrogen atoms, and the intensities of the lines directly correspond to the number of hydrogens producing the sharp signals (Guillén and Ruiz, 2001; Mannina and Segre, 2002).

The oleoyl acyl content of Ayvalık olive oil determined by the current method is closer to the data of 2005 and 2006 (Andjelkovic et al., 2009). However, the fraction of saturated acyls in total is higher while the percentage of linoleoyl acyl is lower than the values reported for Ayvalık olive oil (Andjelkovic et al., 2009). The samples of the Marmara region have a linolenoyl acyl percentage ranging between 1.3 to $0.1 \%$ and 2.1 to $0.1 \%$. The results of Aegean region depict overall higher values of oleoyl acyl content with respect to the Marmara region. Olive oil from Bayındır has almost $80 \%$ oleoyl acyl while the oil from the Aegean region contains the lowest linoleoyl acyl content of $3.4 \pm 0.2 \%$. Similar to the Marmara region, the linoleoyl acyl fraction is the best discriminating factor of the olive oils in the Aegean region. Both the linolenoyl acyl and linoleoyl acyl fractions may be used for distinguishing the geographical origin of the samples from the Mediterranean region (southern Turkey). Among all the samples analyzed in this study, Samandağ olive oil has the highest linolenoyl acyl, saturated acyl, and linoleoyl acyl fractions at 3.0 to $0.1 \%$, 26.5 to $0.6 \%$, and 31.9 to $0.6 \%$, respectively. The olive oil from Alanya has approximately $50-70 \%$ higher linoleoyl acyl content than the rest of the olive oils (excluding Samandağı olive oil). Olive oil from Nizip, in the southeastern region of Turkey, has the same saturated acyl content as the reference Gurdeniz et al. (2008). However, the olive oil from Nizip has lower linoleoyl acyl fraction with respect to the same study about a different season (Gurdeniz et al., 2008). There are two geographical regions, the Black Sea region, and the southeastern region, that do not have direct access to the Mediterranean Sea. For this reason, the number of olive growing towns and cities in the Black Sea and southEeastern regions of Turkey is scarce. This limits the number of olive oil samples to be analyzed from these regions. Despite this fact, it is possible to grow olives in, for instance, Yusufeli, in the Black Sea region (northern Turkey). The olive oil from Yusufeli has approximately 15-25\% lower saturated acyl content with respect to the rest of the samples. This is attributed to the geographical location. Furthermore, the fatty acyl content of Hatay-Samandağı does not reflect the properties of typical virgin olive oil. This very unusual result is attributed to the very high relative humidity of that region. The relative humidity map of the Turkish Meteorology Institute indicates very high humidity, which distinguishes Samandağ 1 from the rest of the olive oil growing regions (Website of Turkish Metrology Institute).

In addition to analyzing olive oil samples from different regions of Turkey, samples from Libya and the Middle East are also analyzed. Table 2 depicts the contents of these oils. The olive oil samples from the Middle East and Libya can be distinguished based on the fractions of linoleoyl acyl and oleoyl acyl. One of the samples from Jordan/ Ibrid and the olive oil from Libya/Benghazi have closer percentages for all the acyls. On the other hand, one of the aims of this study is to analyze several samples from different regions of the same village to show the possibility of distinguishing olive oil samples even in a small area. For this purpose, Kurşunlu village of Bursa/Gemlik, with five samples, was selected (see Table 3). 
The one-dimensional ${ }^{1} \mathrm{H}$ NMR spectra are also analyzed for the determination of minor constituents. The common peaks with low intensity arising from minor components are at $0.67 \mathrm{ppm}, 0.99 \mathrm{ppm}$, $1.66 \mathrm{ppm}, 1.87 \mathrm{ppm}$ (excluding the olive oil from Palestine), 2.15 ppm, 2.42 ppm, 2.79 ppm, 3.62 ppm, $3.71 \mathrm{ppm}$. There is a peak at $1.77 \mathrm{ppm}$ observed only in the spectra of Balıkesir (Gömeç) (1), Balıkesir (Altınova) (2), İzmir (Bağyurdu Erbiller, Bayındır, Kemalpaşa, and Torbalı), Manisa (Kırkağaç), Gaziantep, Artvin (Yusufeli), and Libya (Benghazi). This signal was also observed in the ${ }^{1} \mathrm{H}$ NMR spectra of olive oils from Lazio and Campania in Italy, but not clarified (Alonso-Salces et al., 2010a). This resonance at $1.77 \mathrm{ppm}$ is attributed to erythrodiol (Altun and Ok, 2012). There are also four interesting signals observed in the spectra of Bursa (Gemlik), Izmir (Torbalı), Manisa (Kırkağaç), Hatay (Samandağ) olive oils at $3.50 \mathrm{ppm}, 3.13 \mathrm{ppm}$, $3.31 \mathrm{ppm}$, and $3.02 \mathrm{ppm}$, respectively. The signal at $3.50 \mathrm{ppm}$ is attributed to stigmasterol, campesterol, $\beta$-sitosterol (the sterol fraction), while the other 3 peaks were de-shielded with respect to the fatty acid peaks arising from alcoholic fractions such as cycloartenol and erythrodiol (Alonso-Salces et al., 2010b).

One of the major goals in the current report is to screen the minor constituents of olive oil in detail based on the diffusion coefficients of the minors by ${ }^{1}$ H DOSY NMR, a non-invasive analytical echnique for mixture analysis that does not require prior separation of the components in the mixture (Tsuda et al., 2006). In addition to $1 \mathrm{D}{ }^{1} \mathrm{H}$ NMR quantitative analysis by statistical approaches, the existence of minor fractions in olive oils is further sought by ${ }^{1} \mathrm{H}$ DOSY NMR. The major motivation in doing that is to explore other traces for geographical discrimination studies non-invasively and time effectively without prior sample preparation and treatment. Since DOSY has been recently applied for analyzing bio-diesel (methyl ester) production from triacylglycerol (Socha et al., 2010), it is thought to use DOSY as 'NMR chromatography' for screening minor components in olive oils, instead of chromatography, which was already applied in olive oil analysis (Ballesteros et al. 2006; Rocco and Fanali, 2009) (see Figure 2 and Table 4 for the details). Chromatography has problems related to the oxidation of the sample, with the formation of artifacts during transesterification, and with the separation identification of the methyl esters in the chromatographic trials.

Figure 2 shows a typical ${ }^{1} \mathrm{H}$ DOSY NMR spectrum of an olive oil analyzed in this study. ${ }^{1} \mathrm{H}$ DOSY NMR has been applied for analyzing several of the samples in this contribution to verify the existence of the minors since their signals overlap with the peaks of the major components. Furthermore, the ${ }^{1} \mathrm{H}$ DOSY NMR data, as shown in table 4, depicts some trends directly related to the

TABLE 2. Percentage fraction of Ln (18:3), L (18:2), O (18:1), and S in olive oils from The Middle East and Libya

\begin{tabular}{llcrcc}
\hline Country & City & Ln & L & O & S \\
\hline Palestine & - & $1.4 \pm 0.1$ & $9.2 \pm 0.2$ & $69.6 \pm 0.3$ & $19.8 \pm 0.3$ \\
Palestine & Kufr & $1.4 \pm 0.1$ & $6.4 \pm 0.2$ & $72.3 \pm 0.9$ & $19.9 \pm 1.0$ \\
Jordan & Ibrid (1) & $1.5 \pm 0.1$ & $8.8 \pm 0.4$ & $72.8 \pm 0.9$ & $17.0 \pm 1.2$ \\
Jordan & Ibrid (2) & $1.6 \pm 0.1$ & $10.0 \pm 0.1$ & $66.4 \pm 1.1$ & $22.1 \pm 1.2$ \\
Jordan & Jerash & $1.4 \pm 0.1$ & $4.5 \pm 0.2$ & $77.5 \pm 1.2$ & $16.6 \pm 1.3$ \\
Libya & Benghazi & $1.7 \pm 0.1$ & $9.9 \pm 0.4$ & $66.3 \pm 0.8$ & $22.1 \pm 0.8$ \\
\hline
\end{tabular}

TABLE 3. Percentage of $\operatorname{Ln}(18: 3), \mathrm{L}$ (18:2), $\mathrm{O}$ (18:1), and $\mathrm{S}$ in olive oil samples from the Kurşunlu village of Bursa/Gemlik

\begin{tabular}{llccccc}
\hline & & & \multicolumn{3}{c}{ Percentage fraction of fatty acyl components in olive oils } \\
\cline { 4 - 7 } Village & Region & Date & Ln & L & O & S \\
\hline Kurşunlu & Sea Level (1) & $12 / 20 / 2010$ & $1.3 \pm 0.1$ & $15.0 \pm 0.3$ & $66.7 \pm 0.8$ & $17.0 \pm 0.9$ \\
Kurşunlu & Sea Level (2) & $11 / 27 / 2010$ & $1.4 \pm 0.1$ & $16.6 \pm 0.2$ & $66.8 \pm 1.1$ & $15.1 \pm 1.1$ \\
Kurşunlu & Hillside (1) & $12 / 23 / 2010$ & $1.4 \pm 0.1$ & $7.5 \pm 0.2$ & $75.2 \pm 1.1$ & $16.0 \pm 1.2$ \\
Kurşunlu & Hillside (2) & $11 / 23 / 2010$ & $1.7 \pm 0.1$ & $6.0 \pm 0.3$ & $73.2 \pm 1.0$ & $19.2 \pm 1.1$ \\
Kurşunlu & Hillside (3) & $11 / 15 / 2010$ & $1.5 \pm 0.1$ & $10.1 \pm 0.4$ & $69.0 \pm 1.1$ & $19.4 \pm 0.9$ \\
\hline
\end{tabular}




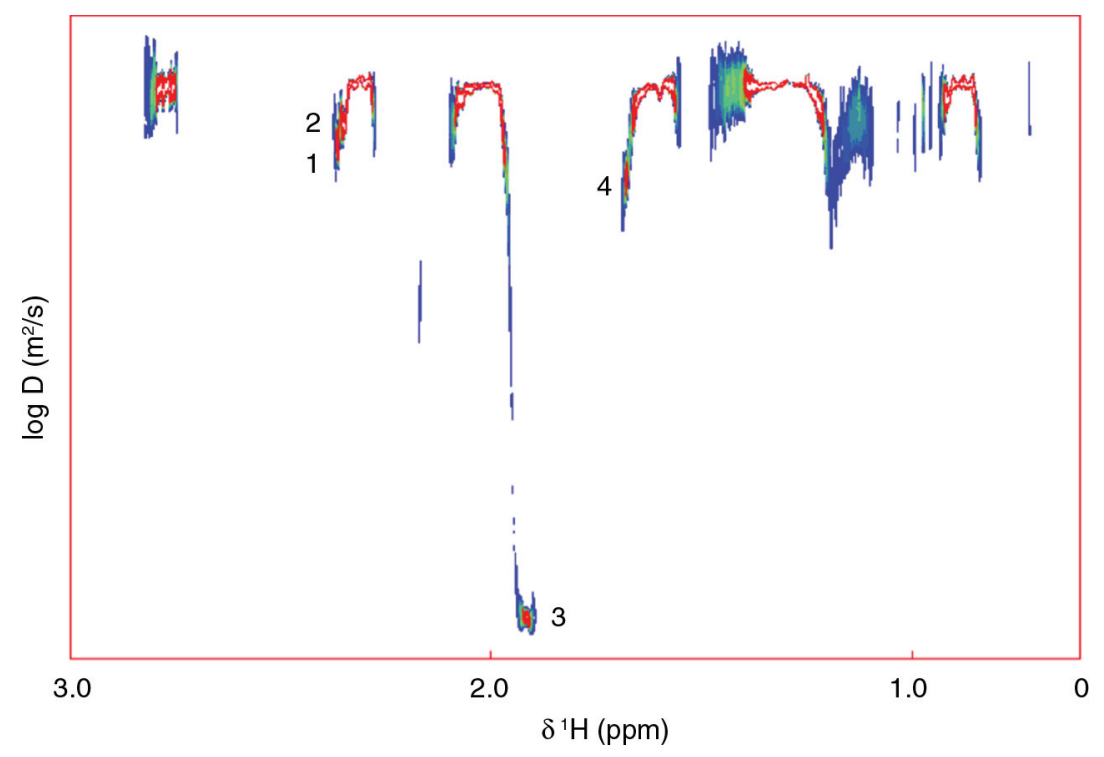

FIGURE 2. ${ }^{1}$ H DOSY NMR spectrum of olive oil from Bursa/Gemlik Kursunlu village Hillside (1). The additional peaks arising from the minor constituents labeled 1,2,3 and 4 are attributed to hydrocarbon and sterol fractions, erhythrodiol, and squalene, respectively.

geographical origin of samples. In analyzing the ${ }^{1} \mathrm{H}$ DOSY spectra, the interest of region is between $0.60 \mathrm{ppm}$ and $3.00 \mathrm{ppm}$. As shown in Figure 2, the diffusion coefficients of the major constituents are all in the same region, attributed to closer molecular weight values (Table 4). Spiking with a reference compound and acquisition of DOSY of the spiked sample can give evidence of the current obtained data. Therefore, the study by Altun and Ok, 2012 is referred to, where each olive oil minor compound was distinguished from each other based on the discriminative NMR signals. The peak at $1.66 \mathrm{ppm}$ in the ${ }^{1} \mathrm{H}$ NMR spectrum of squalene discriminates squalene from the other minor constituents. Sterol fraction has diffusion coefficients in the range of $10^{-9.20} \mathrm{~m}^{2} / \mathrm{s}$ and $10^{-9.40} \mathrm{~m}^{2} / \mathrm{s}$. The diffusion coefficient of squalene is approximately $10^{-9.20} \mathrm{~m}^{2} / \mathrm{s}$. The peak at $0.82 \mathrm{ppm}$, attributed to $\beta$-sitosterol has a diffusion coefficient closer to $10^{-9.20} \mathrm{~m}^{2} / \mathrm{s}$. This is explained by the closer molecular weights of $\beta$-sitosterol $\left(414.72 \mathrm{~g} \cdot \mathrm{mol}^{-1}\right)$ and squalene (410.73 $\left.\mathrm{g} \cdot \mathrm{mol}^{-1}\right)$. The diffusion coefficient of the signals arising from the tocopherol fraction ranges between $10^{-8.83} \mathrm{~m}^{2} / \mathrm{s}$ and $10^{-9.35} \mathrm{~m}^{2} / \mathrm{s}$, attributed to the existence of various tocopherol derivatives.

\section{DISCUSSION}

First the analysis of olive oils from the Marmara (northwestern Turkey) and Aegean (western Turkey) regions is performed. The olive-growing regions of Turkey depict genetic varieties since olive growing is geographically dispersed into five distinct areas. For example, in the Manisa region the olives grown are mainly known as Domat, Uslu (only for oil production), while the Izmir region has a variety of olive tree stereotypes such as Erkence and Çekişte (suitable for both table consumption and oil production), and Gemlik is widespread in the Aegean and Marmara regions of Turkey (Isik et al., 2011; Arslan and Schreine, 2012; Arslan, 2012). The fatty acid composition of different Turkish olive varieties has been also studied (Tanilgan et al., 2007). In the study by Tanilgan et al. (2007) it was shown that, excluding the olive oil of the Uslu type variety, both the saturated and unsaturated fatty acyl fractions of Gemlik, Kilis, Tirilye and Ayvalik varieties were closer. For this reason, in the current contribution, the contents of olive oils are analyzed in order to figure out the most important key parameters for geographical discrimination rather than the other factors influencing the composition of olive oils such as olive variety.

The ANOVA analysis was performed on the content of each fatty acyl (Ln (18:3), L (18:2), O (18:1), and S) calculated from the integral values using the equations mentioned above. As mentioned in the literature, the ANOVA analysis was done for two reasons: i) to figure out the most selective resonance in distinguishing between oils of different regions and ii) to find a possible clustering of olive oil samples from different provinces and geographical regions (D'Imperio et al., 2007). The ANOVA results are shown in Tables 1 and 5. Among 4 resonances considered, only the linoleoyl acyl content variable resulted in significant discrimination between oils of different origin. In analyzing different olive oils 


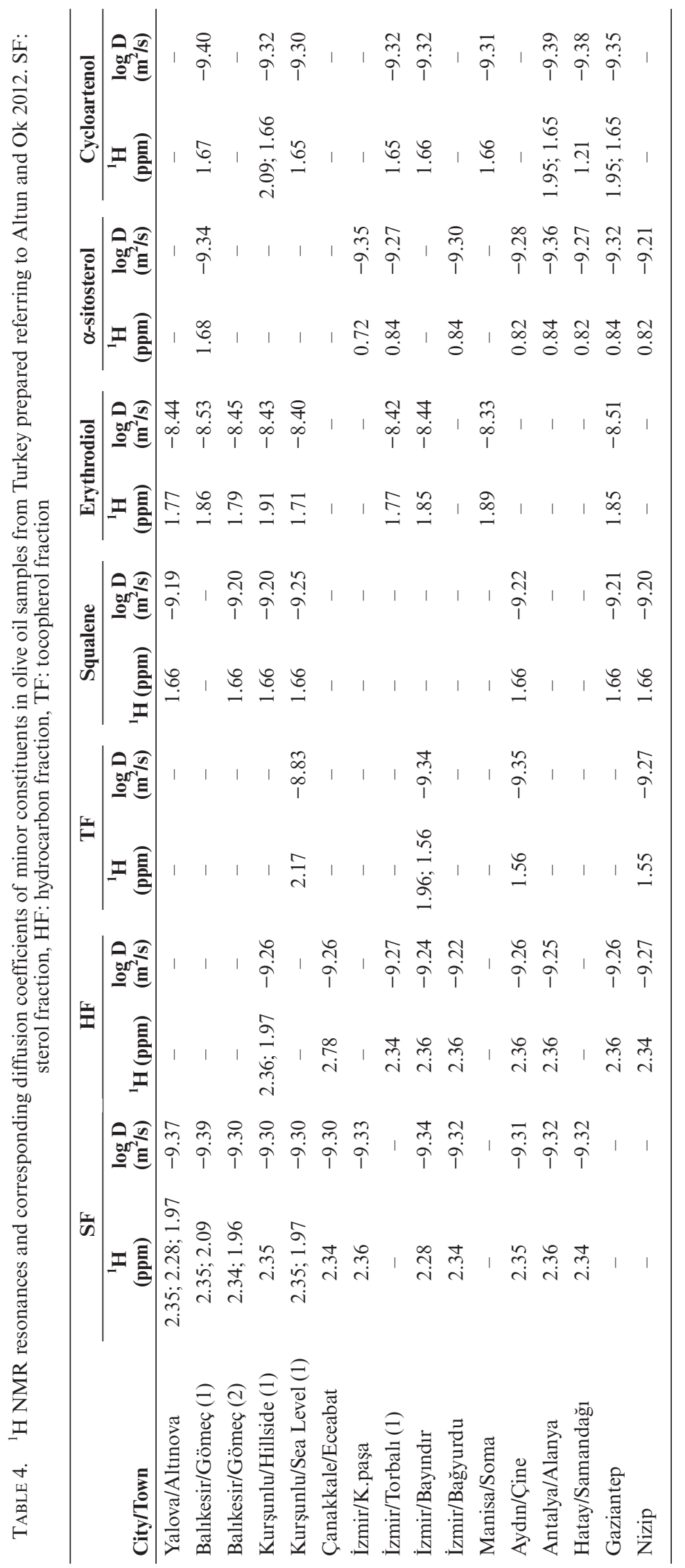


from Lazio/Italy, it was reported that the linolenoyl acyl content, oleoyl acyl fraction and squalene were the most discriminant parameters (D'Imperio et al., 2007). In distinguishing the oils with respect to origin of city, the oil from Artvin/Yusufeli (Black Sea region of northern Turkey) is discriminated easily. Olive oils from Antalya and Hatay (the Mediterranean region of southern Turkey) are apparently different than the rest. Among the olive oil samples from the Aegean region (western Turkey), it is possible to differentiate olive oil samples from Izmir/Kemalpaşa/Ulucak, Aydın/Çine, and Izmir/Torbalı (1). The results of the Marmara region (northwestern Turkey) olive oils distinguish Çanakkale and Yalova/Armutlu samples from the remaining oils. The olive oils of Gaziantep and Gaziantep/Nizip (southeastern Turkey) may be differentiated based on the ANOVA analysis. However, most of the olive oils from especially the Aegean (western Turkey) and Marmara regions (northwestern Turkey) cannot be distinguished from each other due to closer data from different cities of these two regions. For this reason, a further ANOVA analysis with respect to only region origin is performed. In this way, a reliable classification is observed corresponding to the geographical regions examined. The first column in Table 5 indicates a very good clustering from southeastern Aegean (western Turkey), Marmara (northwestern Turkey), Black Sea (northern Turkey), and Mediterranean (southern Turkey) regions, respectively (excluding Çanakkale olive oil). The approach of combining NMR spectroscopy with statistical ANOVA method showed discrimination between olive oil samples from five well-defined geographical regions of Turkey. In a study dedicated to the ${ }^{1} \mathrm{H}$ NMR analysis of the phenolic fraction of twenty-eight olive oil samples

TABLE 5. The clustering of the ANOVA analysis based on the origin of a geographical region. Means for groups in homogeneous subsets are displayed. Harmonic Mean Sample Size=9.305 was used and subset for alpha $=.05$. The group sizes are unequal. The harmonic mean of the group sizes is used. Type I error levels are not guaranteed

\begin{tabular}{lccccc}
\hline City & Region & $\mathbf{1}$ & $\mathbf{2}$ & $\mathbf{3}$ & Sig. \\
\hline Gaziantep & SeR & 5.91 & - & - & 0.1 \\
Manisa & AR & 6.37 & - & - & 0.1 \\
İzmir & AR & 6.53 & - & - & 0.1 \\
Aydin & AR & 7.65 & - & - & 0.1 \\
Yalova & MR & 7.73 & - & - & 0.1 \\
Balıkesir & MR & 7.97 & - & - & 0.1 \\
Bursa & MR & 8.9 & - & - & 0.1 \\
Artvin & BSR & 9.72 & 9.72 & - & 0.2 \\
Çanakkale & MR & 10.8 & 10.8 & - & 0.2 \\
Antalya & MeR & - & 14.2 & - & 0.2 \\
Hatay & MeR & - & - & 20.5 & 1 \\
\hline
\end{tabular}

from three different areas of the Apulia region of Italy, Sacco et al. (2000) reported discrimination between Coast, Hinterland, and North samples. This suggests that the present approach for discriminating among olive oil samples is in accordance with similar studies.

The content of (L, 18:2) distinguishes between the olive oils from the Middle East and Libya. The sample from Jerash in Jordan has the lowest (L, 18:2) acyl content while the same sample has the highest $(\mathrm{O}, 18: 1)$ acyl fraction. Compared to Turkish olive oils, the olive oil from Jerash in Jordan has a higher $(\mathrm{O}, 18: 1)$ acyl content than the rest of the Turkish olive oils (excluding Izmir/Bayındır). Although Hatay/Samandağ is in the Mediterranean region closer to Jordan and Palestine, the data on olive oil from Hatay/Samandağı has completely different fatty acyl values with respect to Jordan and Palestine olive oils. Such a fast screening by ${ }^{1} \mathrm{H}$ NMR helps distinguish the olive oils of the Middle East from the Turkish samples.

As the harvest season is extended in the hillside region of the village, there is a significant increase in the oleoyl acyl content. In addition, the extension in the harvest season at sea level causes a slight increase in the saturated fatty acyl percentage. The data on the hillside and sea level reveal that olive oils from the sea level have higher linoleoyl acyl percentages and lower oleoyl acyl contents. Such composition differences in the case of the Kurşunlu village may be attributed to the altitude difference as discussed in the literature (D'Imperio et al., 2007). A minor component analysis of Kurşunlu olive oil revealed two interesting peaks at $1.93 \mathrm{ppm}$ and $3.35 \mathrm{ppm}$ in the spectra of the samples from the hillside. The one at $1.93 \mathrm{ppm}$ is attributed to the erythrodiol fraction while the one at $3.35 \mathrm{ppm}$ to the cycloartenol (Altun and $\mathrm{Ok}, 2012$ ).

Besides the quantitative NMR analysis with the combination of statistical approach, ${ }^{1} \mathrm{H}$ DOSY NMR results also correlate the existence of minor organic compounds with the geographical origins of the olive oil samples. Squalene was detected in the olive oils from the Marmara and southeastern regions (excluding Çanakkale/Eceabat) while among the olive oils of the Aegean region, squalene was observed only in the sample from Aydin/Çine. In a recent study by Alonso-Salces et al. (2010b) it was mentioned that the squalene signal at $1.67 \mathrm{ppm}$ influenced the statistical discriminative analysis of Turkish olive oil from Spanish, Italian, and Greek olive oils. Moreover, the squalene signal seems to be found in some of the Turkish olive oils but not in all. It seems that the Turkish olive oil samples studied by Alonso-Salces et al. (2010b) were from the Marmara region (northwestern Turkey). Further, a tocopherol fraction was detected only in three different samples (Kurşunlu/Sea Level (1), Nizip, and Aydın/Çine). 


\section{CONCLUSIONS}

In the current study, several olive oil samples from different regions of Turkey, Middle East and Libya have been analyzed. Despite the limited number of samples from some regions, interesting trends were revealed. NMR data seemed to permit the discrimination of extra-virgin olive oils in terms of geographical region rather than providence. The fatty acyl composition data is also helpful in discriminating Turkish olive oil from Jordan, Palestine and Libya samples. It seems that a small area of an olive growing village depicts important sampling for the analyzing parameters of harvest dates, hillside and sea level. Furthermore the quantitative analysis of ${ }^{1} \mathrm{H}$ NMR spectra by the ANOVA method enables the differentiation among geographical origins of olive oils. In particular, the percentage of linoleoyl acyl aided in discriminating olive oils from each other based on well-defined geographical region rather than province. Moreover, the use of $\mathrm{H}$ DOSY instead of chromatography has shown trends in discriminating the origin of olive oil samples by minor constituent determination and clarification. Simple and less time consuming quantitative NMR in combination with a statistical approach are useful in mapping the origin of olive oils from different regions of Turkey and the Middle East. ${ }^{1} \mathrm{H}$ DOSY NMR will be helpful in determining the geographical origin of natural products by detecting the minor organic molecules that may exist in olive oil samples.

\section{ACKNOWLEDGMENTS}

For reference, the author acquired ${ }^{1} \mathrm{H}$ NMR data on minor constituents such as squalene and tocopherol in a pure state at the Institute for Chemistry at Osnabrück University/Germany, and is grateful to the German Science Foundation (DFG) (grant number STE 1127/15-1) for the support of this summer research. The author is also grateful to Atilla Yardimci of the Method Research Company, Istanbul/Turkey for his valuable advice concerning ANOVA analysis.

\section{REFERENCES}

Alonso-Salces RM, Moreno-Rojas JM, Holland MV, Reniero F, Heberger K. 2010a. Virgin olive oil authentication by multivariate analyses of ${ }^{1} \mathrm{H}$ NMR fingerprints and $\delta^{13} \mathrm{C}$ and $\delta^{2} \mathrm{H}$ data. J. Agric. Food Chem. 58, 5586-5596. http:// dx.doi.org/10.1021/jf903989b.

Alonso-Salces RM, Heberger K, Holland MV, MorenoRojas JM, Mariani C, Bellan G, Reniero F, Guillou C. $2010 \mathrm{~b}$. Multivariate analysis of NMR fingerprint of the unsaponifable fraction of virgin olive oils for authentification purposes. Food Chem. 118, 956-965. http://dx.doi. org/10.1016/j.foodchem.2008.09.061

Altun A. Ok S. 2012. NMR analyses and diffusion coefficient determination of minor constituents of olive oil: combined experimental and theoretical studies. J. Chem. Eng. Data 57, 2619-2624. http://dx.doi.org/10.1021/je300804s.
Andjelkovic M, Acun S, Van Hoed V, Verhe R, Van Camp J. 2009. Chemical composition of Turkish olive oil-Ayvalik. $J$. Am. Oil Chem. Soc. 86, 135-140. http://dx.doi.org/10.1007/ s11746-008-1330-y.

Arslan D, Schreiner M. 2012. Chemical characteristics and antioxidant activity of olive oils from Turkish varieties grown in Hatay province. Sci. Horticul. 144, 141-152.

Arslan D. 2012. Physico-chemical characteristics of olive fruits of Turkish varieties from the province of Hatay. Grasas Aceites 63, 158-166. http://dx.doi.org/10.3989/gya.071611.

Ballesteros E, Sánchez AG, Martos NR. 2006. Simultaneous multidetermination of residues of pesticides and polycyclic aromatic hydrocarbons in olive and olive-pomace oils by gas chromatography/tandem mass spectrometry. J. Chrom. A 1111,89-96. http://dx.doi.org/10.1016/j.chroma.2006.01.101.

Degirmencioglu N. 2011. Influence of temperature and modified atmosphere on the chemical profile of packed Gemlik dry-salted olives. J. Food Safety 31, 115-124. http://dx.doi. org/10.1111/j.1745-4565.2010.00274.x.

D'Imperio M, Mannina L, Capitani D, Bidet O, Rossi E, Bucarelli FM, Quaglia GB, Segre A. 2007. NMR and statistical study of olive oils from Lazio: A geographical, ecological and agronomic characterization. Food Chem. 105, 1256-1267. http://dx.doi.org/10.1016/j.foodchem.2007.02.045.

Guillén MD, Ruiz A. 2001. High resolution ${ }^{1} \mathrm{H}$ nuclear magnetic resonance in the study of edible oils and fats. Trends Food Sci. Tech. 12, 328-338. http://dx.doi.org/10.1016/ S0924-2244(01)00101-7.

Gurdeniz G, Ozen B, Tokatli F. 2008. Classification of Turkish olive oils with respect to cultivar, geographic origin and harvest year, using fatty acid profile and mid-IR spectroscopy. Eur. Food Res. Technol. 227, 1275-1281. http:// dx.doi.org/10.1007/s00217-008-0845-7.

Hatzakis E, Koidis A, Boskou D, Dais P. 2008. Determination of phospholipids in olive oil by ${ }^{31} \mathrm{P}$ NMR spectroscopy. J. Agric. Food Chem. 56, 6232-6240. http://dx.doi. org/10.1021/jf800690t.

Ilyasoglu H, Ozcelik B, Van Hoed V, Verhe R. 2010 Characterization of Aegean olive oils by their minor compounds. J. Am. Oil Chem. Soc. 87, 627-636. http://dx.doi. org/10.1007/s11746-009-1538-5.

Isik N, Doganlar S, Frary A. 2011. Genetic diversity of Turkish olive varieties assessed by simple sequence repeat and sequence-related amplified polymorphism markers. Crop Sci. 51, 1646-1654.http://dx.doi.org/10.2135/ cropsci2010.11.0625.

Mannina L, Sobolev AP. 2011. High resolution NMR characterization of olive oils in terms of quality, authenticity and geographical origin. Magn. Reson. Chem. 49, S3-S11. http://dx.doi.org/10.1002/mrc. 2856 .

Mannina L, Segre A. 2002. High resolution nuclear magnetic resonance: From chemical structure to food authenticity. Grasas Aceites 53, 22-33. http://dx.doi.org/10.3989/ gya.2002.v53.i1.287.

Ocakoglu D, Tokatli F, Ozen B, Korel F. 2009. Distribution of simple phenols, phenolic acids and flavonoids in Turkish monovarietal extra virgin olive oils for two harvest years. Food Chem. 113, 401-410. http://dx.doi.org/10.1016/ j.foodchem.2008.07.057.

Rocco A, Fanali S. 2009. Analysis of phytosterols in extravirgin olive oil by nano-liquid chromatography. J. Chrom. A 1216, 7173-7178. http://dx.doi.org/10.1016/ j.chroma.2009.03.081.

Sacchi R, Mannina L, Fiordiponti P, Barone P, Paolillo L, Patumi M, Segre A. 1998. Characterization of Italian extra virgin olive oils using ${ }^{1}$ H-NMR spectroscopy. J. Agric. Food Chem. 46, 3947-3951. http://dx.doi.org/10.1021/jf9706661.

Sacchi R, Addeo F, Paolillo L. 1997. ${ }^{1} \mathrm{H}$ and ${ }^{13} \mathrm{C}$ NMR of virgin olive oil. An overview. Magn. Res. in Chem. 35, 133-145. http://dx.doi.org/10.1002/(SICI)1097-458X(199712)35:13 $\% 3$ CS133::AID-OMR213\%3E3.0.CO;2-K.

Sacchi R, Patumi M, Fontanazz G, Barone P, Fiordiponti P, Mannina L, Rossi E, Segre AL. 1996. A High-Field ${ }^{1} \mathrm{H}$ nuclear magnetic resonance study of the minor components in virgin olive oils. J. Am. Oil Chem. Soc. 73, 747758. http://dx.doi.org/10.1007/BF02517951. 
Fast screening of turkish olive oil by NMR spectroscopy for geographical determination and discrimination purposes $\bullet 11$

Sacco A, Brescia MA, Liuzzi V, Reniero F, Guillo C, Ghelli S, van der Meer P. 2000. Characterization of Italian olive oils based on analytical and nuclear magnetic resonance determinations. J. Am. Oil Chem. Soc. 77, 619-625. http:// dx.doi.org/10.1007/s11746-000-0100-y.

Segre AL, Mannina L. 1997. ${ }^{1} \mathrm{H}$ NMR study of edible oils. Rec. Res. Dev. Oil Chem. 1, 297-308.

Socha AM, Kagan G, Li W, Hopson R, Sello JK, Williard PG. 2010. Diffusion coefficient-formula weight correlation analysis via diffusion-ordered nuclear magnetic resonance spectroscopy (DOSY NMR) to examine acylglycerol mixtures and biodiesel production. Energy Fuels 24, 45184521. http://dx.doi.org/10.1021/ef100545a.

Tanilgan K, Ozcan MM, Unver A. 2007. Physical and chemical characteristics of five Turkish olie (Olea europea L.) varieties and their oils. Grasas Aceites 58, 142-147.
Tsuda M, Yasudo T, Fukushi E, Kawabata J, Sekiguchi M, Fromont J, Kobayashi J. 2006. Agesamides A and B, bromopyrrole alkaloids from sponge agelas species: application of DOSY for chemical screening of new metabolites. Org. Lett. 8, 4235-4238. http://dx.doi.org/10.1021/ol061464q.

Zamora R, Alba V, Hidalgo FJ. 2001. Use of high-resolution ${ }^{13} \mathrm{C}$ nuclear magnetic resonance spectroscopy for the screening of virgin olive oils. J. Am. Oil Chem. Soc. 78, 89-94. http://dx.doi.org/10.1007/s11746-001-0225-z.

Zeiner M, Steffan I, Cindric IJ. 2005. Determination of trace elements in olive oil by ICP-AES and ETA-AAS: A pilot study on the geographical characterization. Microchem. J. 81, 171-176. http://dx.doi.org/10.1016/j.microc.2004.12.002.

Website of Turkish Meteorology Institute indicating the relative humidity map, updated daily: http://www.dmi.gov.tr/ tarim/nem-tahmini.aspx. 